Marquette University

e-Publications@Marquette

Social and Cultural Sciences Faculty Research and

Publications

Social and Cultural Sciences, Department of

$12-6-2012$

\title{
Difficult Dialogues: The Technologies and Limits of Reconciliation
}

Dawne Moon

Marquette University, dawne.moon@marquette.edu

Published version. "Difficult Dialogues: The Technologies and Limits of Reconciliation," in Religion on the Edge: De-centering and Re-centering the Sociology of Religion. Eds. Courtney Bender; et al. New York : Oxford University Press, 2012: 179-199. Permalink. (C) 2012 Oxford University Press. Used with permission. 


\title{
8 \\ Difficult Dialogues: \\ The Technologies and \\ Limits of Reconciliation
}

\author{
DAWNE MOON
}

Projects known as dialogue or reconciliation build on the common ground between members of historically adversarial groups to help overcome vicious cycles of retaliation. They do so by helping people to relate, in Martin Buber's (1970 [1923]) sense of the term, to those they perceive as "Other," and thus to transform through interaction how they define themselves. While some posit that the deep interpersonal understanding that reconciliation fosters is actually central to most or all religious traditions, reconciliation projects can also facilitate a mode of non-institutional spirituality, thus inviting us to explore one of the sociology of religion's "edges" this volume seeks to re-center. In this mode, participants may see institutional religion as fallible and human but see reconciliation as bringing contact with something transcendent and universal - a truth long known in their particular religious heritage, and others as well, but forgotten in many institutions. Such reconciliation projects may be experienced as "spiritual" rather than "religious," transforming selves precisely by bringing together people who might normally be institutionally segregated. At the same time, instances such as those I discuss here can only arise when they are explicitly distanced from politics, and thus paradoxically they may reproduce the very hierarchies some participants wish to overcome.

While this research ventures outside of congregations and looks at movements that cross religious boundaries, its real force lies at a different edge of the sociology of religion by helping us to locate the ambiguous effects of the "spiritual"-feeling efforts at dialogue or reconciliation and the ways these efforts can both inspire and frustrate desires for political transformation and equality. It has been argued that lasting political transformation depends on changes in how people identify themselves as members of a group in relation to 
other groups (Todd 2005). Not all participants are drawn to reconciliation/dialogue because they want to effect political change, however; many simply are tired of political conflict and the violence it involves. For these dialogue efforts to be fully effective, they need parties from either side of a historical conflict, and this is why it resides at a point of tension. To elucidate this tension, I begin by exploring how these groups can be effective; I then explore the limitations of dialogue, focusing on the paradox that emerges when the groups in question are characterized by an imbalance of power or privilege.

I compare observations from two studies of religious and religio-ethnic communities. The more recent is a qualitative study of American Jews' understandings and experiences of anti-Semitism and how it relates to politics, particularly around the Israeli-Palestinian conflict. ${ }^{1}$ I compare some of the findings from this study with findings that emerged in my earlier ethnographic research on debates about homosexuality within the United Methodist Church (Moon 2004, 2005a, 2005b). In the broader study of American Jews and their understandings and experiences of anti-Semitism, I used voice-recorded intensive interviews with a snowball sample of thirty-two respondents, ranging from one hour to three-and-one-half hours. ${ }^{2}$ Here I focus on two closely related organizations that were a subset of this research, an international dialogue and peace organization called Listening with Love, and a loose network of local groups called Palestinian-Jewish Reconciliation Circles that meet monthly, usually in different members' homes, to share their stories and practice listening attentively to each other in order to overcome suspicion, defensiveness, and hatred. ${ }^{3}$ Interviews were grounded in and supplemented with participant observation in workshops and public forums, including a two-weekend training session with Listening with Love and a four-day retreat organized by the core members of a Reconciliation Circle. I also draw here from interviews with members of an organization called Jews for a Just and Lasting Peace, which engages the conflict in the Middle East at the political level, but whose members echo some principles of dialogue. Because these concepts grew out of a study of Jews, I have so far interviewed a relatively small number of Palestinians. While Palestinian perspectives will be the focus of future research, critiques that have emerged in the current research have been sufficient to point to some of the tensions inherent in dialogue and reconciliation.

Discussions of the Israeli-Palestinian conflict are invariably controversial, especially when one discusses power. To be sure, there is a huge range of opinion among Israelis, Palestinians, and others who identify with either or both groups, and this chapter explores some of the middle ground. However, the basic conflict might be roughly summarized as follows. To many Palestinians, Israel is a militarily strong occupying government founded unjustly and illegitimately on Palestinian lands, and now funded largely by the United States, whose forces have and continue to dispossess and dehumanize people in the West Bank and 
Gaza by taking away their livelihoods; cordoning them off into isolated areas where water, food, and medical treatment are scarce and difficult to access; tearing down people's homes at will; appropriating their land; imprisoning people indefinitely without charge; and consigning people to refugee camps. While Palestinian citizens of Israel are treated better and have some rights, they experience discrimination, for instance, in unrecognized Arab towns that receive inferior government services. To many who identify with the state of Israel, Palestinians are a group of Arabs, politically backed (but perhaps abandoned when it comes to humanitarian support) by the entire Arab world, determined to eradicate the Jewish presence in the Middle East and killing Israelis in random terrorist attacks to make their point. ${ }^{4}$ During the Nazi Holocaust, which was one among many large-scale attacks on Jews historically, many Jewish refugees literally had nowhere to go; shiploads of people were turned away from the United States and other countries and sent back to Europe to face whatever dangers they might. The state of Israel, born in the wake of World War II, became both a symbol of redemption and a desperately needed refuge. That refuge is a tiny country, the size of New Jersey, subject to attacks, both violent and discursive. Some have argued that the state of Israel is subject to a "new anti-Semitism" that uses the same tropes as traditional anti-Semitism but on a global scale: they see the Jewish state being verbally attacked and delegitimated, held accountable for offenses that draw little international notice when committed by other countries, and scapegoated for offenses committed by many governments (Chesler 2003; Dershowitz 2003; Foxman 2003). Many of my Jewish interview subjects identified to some extent with the state of Israel, and at the same time, many were critical of its treatment of the Palestinians.

My interview pool was not representative of the American Jewish public. ${ }^{5}$ Most of the Jews I spoke to in this research came from families that ardently supported the state of Israel, but many respondents experienced a feeling of awakening when they learned of the Palestinian perspective. Some went to Israel and saw the way Palestinian citizens of Israel, as well as residents of the West Bank or Gaza, were treated. For others that feeling came when they saw a play or read a book that prompted them to question the definition of the situation with which they had grown up, and for others yet it was simple exhaustion with all the violence that led them to look for a way to bring about peace or prompted them to find out "the other side of the story." Some have come to the conclusion after looking into the situation that Israel has the upper hand in relations with the Palestinians in terms of wealth and military power. Rather than seeing terrorism against Israel as one among many examples throughout world history of anti-Semitism-the term David Norman Smith (1996) reserves for the mythologization of Jews as chimeric monsters (controllers of the world economy and media, eaters of Christian children, and the like)-some see attacks on the state of Israel as part of an ordinary conflict like other international conflicts 
over ordinary issues including borders and resources. ${ }^{6}$ Given that the IsraeliPalestinian conflict is one of the two main factors Cohen and Eisen (2000) see as contributing to a decline in the centrality of the state of Israel to American Jews, it is likely that these findings may become more relevant in the future.

\section{Theorizing the Self in Interaction}

This chapter explores the intersection of politics with the self, which sociological theories of the self have generally ignored. Mead (1967 [1934]) argued that to be a person means internalizing the generalized other's view of the "me," seeing myself as others see me. He argued that we only become persons in interaction, that each human organism (his term) is at once an individual "I" and an embodiment of his or her society, an object to himself or herself as much as to those around him or her. But for all his importance and influence in sociology, Mead's concept of the generalized other is a bit too simple. ${ }^{7}$ The concepts of Martin Buber (1965, 1970 [1923]) help us to understand the transformation of the self that can occur in dialogue to produce intersubjectivity between parties who once viewed each other as Other, as outside their moral world. Like Pagis's study of Vipassana meditation (this volume), attention to Buber's analysis helps us to rethink Mead's conception of the self and its relationship to the generalized other.

For Buber, the inherent duality of humanity is not "the I and the me," as it is for Mead, but two kinds of "I." He distinguishes the "I" in an I-it experiencewhen the other is regarded as an object of contemplation, of discovery, even of affection - from the "I" in an intimate, $I$-you ( $I$ ch-Du, often translated as $I$-thou) relationship. ${ }^{8}$ For Buber, a relationship with the intimate you occurs when for each person the other is "infinitely there," touching the core of the self. It may sound a bit mystical, but as a sociologist, Buber insisted that the communion between souls that can happen when they relate in what he calls dialogue is a real occurrence, much as the communion people experience in collective effervescence is a concrete, empirical reality in Durkheim's (1995 [1912]) theorization. As Buber explains in his 1929 essay "Dialogue," to engage in dialogue is to open oneself to being touched at the core, stepping out of the "armor" we wear in everyday life. For Buber, when someone "says" something to me, in a song, a sermon, a lecture, or a conversation, for instance, he or she touches me at the core. To be attentive is Buber's term for being open to such a connection.

Buber is careful to point out that $I$-it interactions are essential, and not necessarily negative; asking a professor to explain a concept, for instance, or asking for directions or medical advice is essential to functioning in the world, but a problem emerges when this kind of interaction is mistaken for relating. For Buber, the $I$ of the $I$-it experience is the ego, who "occupies himself with 
his My: my manner, my race, my works, my genius," while the $I$ of the $I$-you relationship is the person, who is open to "infinite conversation" (1970 [1923], 114). He remarks:

Egos appear by setting themselves apart from other egos.

Persons appear by entering into relation to other persons.

One is the spiritual form of natural differentiation, the other that of natural association.

The purpose of setting oneself apart is to experience and use ....

The purpose of relation is the relation itself-touching the You. (1970

[1923], 112-113)

For Buber, relating to another person transforms the self; its lack of instrumentality and its mutual understanding resonate with Habermas's concept of communicative rationality. We have all probably had such moments, though like affect, they are difficult to know in another or to describe in any way resembling "objectivity."

Buber distinguishes true relating from imitations. He distinguishes "genuine dialogue" from "technical dialogue," which is solely concerned with gaining objective understanding, and "monologue disguised as dialogue," in which "two or more men, meeting in space, speak each with himself in strangely tortuous and circuitous ways and yet imagine they have escaped the torment of being thrown back on their own resources" (a description that evokes graduate seminars a bit more than any of us might like; 1965, 19). Under this heading, he includes debate, in which "in the speaking are so pointed that they may strike home in the sharpest way, and moreover without the men that are spoken to being regarded in anyway present as persons"; conversation, marked "solely by the desire to have one's own self-reliance confirmed by marking the impression that is made"; and other facsimiles of dialogue that separate people rather than connect them (1965, 19-20). These distinctions acknowledge that genuine dialogue can be difficult to achieve, especially when egos intervene. I suggest that egos are not the only thing that can intervene; hierarchies of authority can prevent relating, even as relating can disrupt hierarchy.

The dialogue groups I observed work by getting people into a room together with those they view as opponents and keeping them all coming back. Such processes thus depend on participants not becoming too alienated or threatened, even if the legitimacy of their tacit authority is challenged. Since discussions of politics can easily degenerate from debate into shouting matches that could drain participants of energy for no reward, dialogue groups walk a fine line. As Amanda Udis-Kessler (2008) demonstrates in her study of the United Methodist General Conference of 2000, when opponents convene to 
make policy decisions without the transformation of consciousness that comes from relating to each other in Buber's sense, the interaction can feel like a war between groups from utterly different moral worlds (see also Hunter 1992). Thus, dialogue groups endeavor to avoid politics, focusing on giving each participant the time and space to "tell their story," speaking "from their hearts." In doing so, they give participants the opportunity to humanize each other, to see each other as members of the same moral community (Baumann 1989; Fein 1979; Tavuchis 1991). Broadening the moral community changes the "generalized other" one internalizes, and thus changes the self by internalizing the gaze of, rather than repudiating, those once deemed anathema.

\section{Relating Versus Knowing One}

Buber's distinction between relating and experiencing helps us to understand a puzzle that emerged in my earlier research on debates about homosexuality in the United Methodist Church, or UMC. I would ask my interview respondents how they had come to their current views. Those who believed that homosexuality was sinful cited a range of things: the Bible, their comfort about their convictions (which, as one woman remarked, God would surely disturb were she on the wrong track), their knowledge that God loved order and that homosexuality flouted it. In contrast, I was struck by pro-gay church members' recurring accounts of gay people close to them: a brother who had come out recently; a gay friend, relative, or child; a speaker who expressed pain at being shut out of the church. In spite of the mainstream lesbian, gay, bisexual, and transgender (LGBT) movement's strategy of "coming out," encouraging every LGBT person to make her or his sexual orientation or gender identity known to friends, coworkers, neighbors, and everyone else, it seemed a facile truism that "knowing one" made all the difference. After all, plenty of members of the congregations I studied also knew gay men or lesbians and still believed homosexuality to be sinful-in their view, wanting to be nice to gay men and lesbians at the expense of upholding the word of God was understandable, but sinful, and would condemn to hell those one should be helping to find salvation. Similarly, in Udis-Kessler's study, pro-gay "inclusionists" chanted slogans such as "See our people" and "Know your people" $(2008,64)$ and tried to encourage delegates to get to know LGBT participants, but neither strategy moved those who believed that knowing gay people was beside the fact that homosexuality was sinful. Again, the assumption that "knowing one" was sufficient to change minds led pro-gay members to make an argument that seemed irrelevant to their opponents.

When my research moved into the arena of American Jewish understandings of anti-Semitism and its relationship to Middle East politics, I finally 
understood what I had been seeing. Again, the theme of "knowing one" came back. For instance, Julia, a 57-year-old Jewish environmental activist and artist, told me about how reading Israeli geographer Meron Benvenisti's (2002) Sacred Landscape opened her eyes to the Palestinians' experience of Israel, a country she had loved since her childhood. She remarked:

And you know it's a great sadness to me, one of the first things I'll often say to a Jewish person if they have a lot of, you know, what I would say are misperceptions, I would say, "Have you, do you have any Palestinian friends? Do you even know any Palestinians?" And almost across the board, no. They might have met a Palestinian shopkeeper. They never exchanged stories. After I read that book I went around and I would meet Palestinians in many places, there are lots of them here and as soon as they might say where they were from, Ramallah or Hebron or somewhere, I would say, "My name is Julia, I'm Jewish, I'm really sorry." And instantly, every one of them, from old, grizzled men to young girls, all, just filled with the anger of the Palestinian cause, would embrace me. Every one of them would open their heart immediately, just by my saying that, just saying, "I understand what happened to your people, and I'm sorry." And one couple of brothers in Taos, New Mexico, they brought out the Qur'an and showed me where Muhammad says, "See, he says we're supposed to all be like brothers, Christian, Jew, and Muslims across the board." Just saying I'm a Jewish person and I'm sorry for what happened to them. I couldn't help it. I just felt so terrible. ${ }^{10}$

Nicholas Tavuchis (1991) argues that apology is an effort to reestablish membership in one's moral community when one has violated its norms, saying:

[A]pology expresses itself as the exigency of a painful re-membering, literally of being mindful again of what we were and had as members and, at the same time, what we have jeopardized or lost by virtue of our offensive speech or action. And it is only by personally acknowledging ultimate responsibility, expressing genuine sorrow and regret... that the offender simultaneously recalls and is re-called to that which binds. $(1991,8)$

In Julia's case, the apology is to people who are often seen as belonging to a different moral community; Julia's apology is in effect a claim that she and those to whom she is apologizing do belong to the same moral community, a claim affirmed in the New Mexico men's invocation of the Qur'an. It is not simply "knowing one" that makes the difference; relating, in Buber's sense, implies seeing another as part of one's moral community, or as Habermas might say, as part of one's lifeworld. 
Julia described a trip she had taken to Israel with Listening with Love (LWL), an international organization that seeks to foster relating between members of historically opposed groups. The organization offers training and practice sessions to teach antagonists to hear and understand each other so they may move beyond the cycle of mutual suspicion, hatred, and defensiveness. Listening with Love posits that human beings are all linked by a core, fundamental "essence" of "values that we all share," including love, safety, compassion, beauty, courage, creativity, freedom, friendship, generosity, joy, truth, trust, and the like, and its organizers facilitate dialogue between Jews and Arabs, Jews and Germans, and other historically antagonistic groups. The organization also offers training sessions so that people may learn their techniques and apply them in their daily lives. At the training session I attended, facilitators presented their model: each human being has a core, which has been wounded by life's disappointments, injuries, injustices, and attacks. Defenses, or what Buber $(1965,10-11)$ calls "armor," have grown to protect those wounds and the vulnerable core, but they can be counterproductive as they often prevent people from relating to each other, or in LWL's terms, from seeing each other's "true self." The organization teaches that the extreme of defenses arguing back and forth at each other is war, but when people can open themselves to each other, telling their stories and being heard, then peace is possible.

The process thus resembles the evangelical Protestant process of racial reconciliation that Emerson and Smith (2000) discuss. In their account, which summarizes Yancey's (1998) analysis, reconciliation as it was defined by the early founders of the movement takes place in four steps: (1) developing primary relationships across racial lines, (2) recognizing social structures of inequality, (3) whites' repenting "of their personal, historical, and social sins," and (4) African Americans' willingness to forgive, individually and corporately, when asked, repenting of anger and whatever hatred they hold toward whites and the system (see Emerson and Smith 2000, 54-55). As Emerson and Smith found, however, the recognition of social structural imbalance implicit in the model brought a political element into reconciliation that cohered in no way with white evangelicals' worldview and thus found resistance. Efforts at reconciliation without acknowledgement of social structural hierarchies could result in blacks feeling that their white counterparts were making a shallow effort at best. Emerson and Smith describe the beginnings of reconciliation theology in the late 1960 s and early 1970s, saying:

Some of the white elite evangelicals attempted reconciliation, but incompletely. The problem with whites' conception of reconciliation, many claimed, was that they did not seek true justice - that is, justice both individually and collectively. Without this component, 
reconciliation was cheap, artificial, and mere words. It was rather like a big brother shoving his little brother to the ground, apologizing, and then shoving him to the ground again. $(2000,58)$

Later, I will explore similar political tensions in the dialogue/reconciliation movements I discuss here, but first it is important to acknowledge that even when the process is incomplete, it can have some of its desired effects. First, dialogue and reconciliation processes can indeed help to humanize adversaries, which may be no small feat. At a retreat organized by the PalestinianJewish Reconciliation Circle, a Palestinian-American woman I estimated to be in her thirties who was active in the movement spoke of having been raised on stories of what "the Jews" did to her family in 1948-taking their homes, making them into refugees. She felt she was raised to hate, but she didn't want to raise her own children that way, so the Reconciliation Circle offered her the opportunity to overcome that legacy without having to forget the past. Others, who had never had the opportunity to talk to someone from the other side of the Israeli-Palestinian conflict, became friends with them and felt hope that peace was actually possible. At a press conference after the event, an Israeli woman whose son was serving in the Israeli army spoke of having met a 16-year-old exchange student to the United States from Iraq:

He said, "Don't hate me, but growing up, my parents taught me that we have to hate you, that you are awful people." After a half hour of wonderful dialogue, he said, "I'm sorry I feel this way; you are actually sweet." We greeted each other every morning with a smile and a kiss; now I'm going home to tell my son that peace is possible. [Reconstructed in notes]

While simply learning that adversaries are human might seem so simple as to be banal, it can actually be profoundly terrifying, troubling one's worldview and pre-existing relationships. Ken, a 69-year-old retired pediatrician and the organizer of a Reconciliation Circle, remarked on the "great courage" it can take to participate, mostly because of the fear of what one's "own people" would say. He commented:

We're talking about fear. Fear, part of it is fear not only of the Other, but also of your own people... You're seen as a traitor, you're seen as naïve, you're seen as not intelligent, which is a terrible thing in the Jewish community. You're seen as on the Left. Oh my goodness. It takes great courage to move out to the Other. You take flak from your own people, usually. 
To illustrate this difficulty, Ken told me about an incident with a local newspaper:

The most powerful criticism dynamic that I have had is, a couple of years ago, in the local Jewish newspaper, there was exaggerated demonization of the Palestinian people, the Palestinian schools, and the Palestinian textbooks. And I am familiar with the university-based research about those things. And this article was hateful. And there was a photograph of like a 3-year-old Palestinian with a Kalashnikov, semiautomatic rifle that somebody took somewhere... [a]nd the point was, "They're teaching all their children to kill all the Jews." And I just couldn't [let that go], so I wrote an OpEd, an opinion-editorial, and I simply quoted the Israeli academicians and their findings of the Palestinian textbooks, and schools.... I just quoted academics, but [people in the area] projected the worst things onto [my wife] and me, and onto the Reconciliation Circle. They took out ads, actually, in the newspaper....And, they just called us all the names, you know: naïve, traitors, um, Arab-sympathizers....

In his comments, he demonstrated the effectiveness of the dialogue techniques he had honed in the Reconciliation Circle, saying:

And you know what I did? I phoned every one of them. And you know what? The ads disappeared, in two weeks the letters were over, and I would say I'm still in relationship with the people who wrote them. I phoned them and I really listened to them. I asked them what their stories were, I got into their frame of reference. They felt heard. I felt understood. I told them what my motive was. It wasn't done from a distance of blaming or fist-[shaking] across a campus green.

In addition to humanizing the Other, Ken reveals how such processes can impart skills for de-escalating conflicts, as well as building relationships with past adversaries.

Habermas's distinction between the formal world and the lifeworld is instructive. The lifeworld is what constitutes mutual understanding, while formal world concepts constitute a reference system about which mutual understanding is possible $(1981,126)$. The lifeworld is the realm of the taken-for-granted and, in Buber's terms, of the real relationships that shape us at the core, while the formal system is a realm of solely $I$-it interactions. To problematize the lifeworld is to destabilize a person's whole worldview and problematize the core of the person, as happens when people observe a reality that does not conform to their symbolic imaginary: when people from either side realize that the Israeli-Palestinian conflict is not the battle between good and evil they may 
have assumed it to be, or when they realize homosexuality is not actually the derangement or evil it symbolizes in heterosexist common sense.

Dialogue humanizes the Other, transforming the self in the process. When dialogue works best, participants come to see each other not as representatives of evil forces that have been out to destroy them, but "as human beings"; in other words, like apology in Tavuchis's formulation, dialogue allows people to see each other as members of the same moral community. Even people who have hurt and killed others, such as Combatants for Peace (the real name of an organization of former Israeli soldiers and Palestinian fighters), can come together, admit to the harm they have caused others, and explain why it seemed justified at the time, as well as how they have since come to see otherwise. People who seemed to occupy the formal world, the world of objects-violent, oppressive, frightening, selfish, impure, chaotic - enter into the lifeworld, the realm where mutual understanding is possible, the realm of relating. Regarding the Israeli-Palestinian conflict, dialogue participants come to see people who "love peace" as part of the "us," while they see those who seem to prefer wargovernments, war profiteers, the hateful-as the redefined outsiders. They do so at some risk, however - they risk the security of their old view for the unknown. In Ken's words, they risk alienating their "own people"; they stand to forego a relatively popular position of "we're good, they're evil" for a rarer one, and most frighteningly for detractors, they risk making themselves open and vulnerable to people who could exploit their weaknesses.

When Jewish people such as Ken and Julia related to Arabs and Arab Americans, and when Arabs related to Jews, they regarded the Other as part of their moral community, and it was simply implausible that an entire people could be inherently violent, less loving, or less deserving of a happy life. Similarly, relating to someone who was gay or lesbian, in my earlier research, made the stigmatization of gays and lesbians seem preposterous, dangerous, and profoundly unfair. When respondents, including some members of the conservative congregation I studied, related to gay men or lesbians, it became implausible to them that God could find gay intimacy more sinful than hetexosexual intimacy or find gay people to be less capable than heterosexuals of doing God's work. The distinction between knowing and relating helps to explain why pro-gay strategies fail to transform those who believe homosexuality is sinful-relating emerges organically; like collective effervescence, it cannot be simply willed into existence among the unwilling.

\section{The Politics of Dialogue}

To introduce the concept of dialogue, Buber tells a story about a meeting he attended in 1914, where someone raised an objection to too many Jews being 
nominated to help form an international organization. Sensing anti-Semitism on the part of the objector, Buber raised his own objection. He writes:

I no longer know how from that I came to speak of Jesus and to say that we Jews knew him from within, in the impulses and stirrings of his Jewish being, in a way that remains inaccessible to the peoples submissive to him. "In a way that remains inaccessible to you"-so I directly addressed the former clergyman. He stood up, I too stood, we looked into the heart of one another's eyes. "It is gone," he said, and before everyone we gave each other the kiss of brotherhood.... In this transformation dialogue was fulfilled. Opinions were gone, in a bodily way the factual took place. $(1965,5-6)$

In Buber's account, speaking from his heart to someone open to him transformed the man, his objection, and their relationship. But what if the Christian man had not been open to Buber's words? What if he felt a personal stake in maintaining his authority as a Christian to decide how many Jews should be permitted into their group?

What those who called Ken a traitor may have sensed was that in addition to humanizing the other and teaching skills for de-escalating conflict, dialogue can inspire people to learn about power dynamics they hadn't known about, a step Yancey sees as crucial to early reconciliation theologians' process. For instance, Julia, who had gone on the trip to Israel with LWL, remarked:

One reason I went on this trip is that I felt that so many Jews didn't have the full story. That we had been given a lot of information that didn't allow us to see and understand the humanity of the other side and their suffering.... I wanted to go and with my own eyes and ears come back with the stories that I could then bring back to Jews. And part of me felt like, "Well, Israel doesn't really need the American Jews," but it turns out so much money is coming from American Jews that's going into terrible projects, that are making things worse, that Israel desperately needs an enlightened American Jewish public. In fact, the American Jewish [public] is more proZionist than the Israelis by and large. Because we're blinder, because we're not living there and not seeing and understanding the complexity, the great complexity, the chaos and confusion and the suffering on all sides.

Similarly, 42-year-old Lisa belonged to Jews for a Just and Lasting Peace (JJLP), an organization that seeks to work in solidarity with the Palestinians. 
Having grown up with a grandfather she admired and saw as a model of Jewish ethics, she had always understood that being Jewish meant both fighting racism and supporting the state of Israel. She experienced a moral crisis upon her first visit to Israel and Gaza when she was in her twenties, having seen Israelis treat Palestinians in ways she could only describe as profoundly racist. She told me of the difficulties she had with her father over the Israeli-Palestinian conflict, given their family's intense commitment to Zionism. Lisa remarked:

[My partner] is very close to my dad, and she said, "The thing about your dad that's so funny, is that if he were traveling and met a Palestinian family over dinner he would fall in love with them, and he'd be the first person sitting there crying, listening to their story. He would so, on a heart level, connect to them." And so for people like that, which is most of us really, that's an important thing that he has to experience, to get to break through this ignor-you know, naïveté.

For Lisa and others, as for the reconciliation theologians Yancey discusses, humanizing the other was a tremendous first step, but insufficient. When I told Lisa that some of her comments resembled those of members of the Reconciliation Circle, she remarked:

I haven't done [Reconciliation Circle work], but the critique is there's no political analysis. And what I'm talking about, just trying to talk to people in your family, just trying to get through that, the barrier is emotional. But of course what you need to get it to is the actual political analysis of how we can make it better... I mean my hope would be, with the dialogue groups, [that] people realized we need some more, real, fair peace negotiations. That it's actionable, instead of, you know, a warm and fuzzy feeling. But yeah, I think all that has to happen.

This politicization speaks to a tension involved in dialogue or reconciliation. Talking about one's own feelings and experiences and telling one's personal story are the means; participants are urged to avoid talking about politics, precisely because "politics" involves polarization, needing to win, and armoring instead of opening oneself to the other. Yet deep beneath the surface, the ends seem to have a political aspect-once people learn to humanize each other, they may well come at some level to advocate political transformation. They may even come to understand their own people as benefiting from an imbalance of power and privilege. If they state that outright, then those who oppose such analyses will object to dialogue. But if they do not, they do a difficult 
dance, as 69-year-old JJLP member Diane remarked about her own experience at a previous Reconciliation Circle retreat:

They put us in little talking groups, at different times, and I was with an Israeli Jew and an Israeli Palestinian, who lived neighboring towns, and who had just put a niche in their fenced off area and some of the parents and some of the children were doing projects together, and being nice to each other. And you could see, they were both extremely nice men, and you could see how very fond they were of each other. The question [we were given to discuss] was something like, "What's causing this rift, or this conflict?" and they were very careful, you know, the Israeli Palestinian didn't say that what's causing this conflict is that we're being oppressed and persecuted, and I said, "It seems to me you can't have balance. You're talking about a mighty military power and a basically unarmed people trying to hold on." And so that, I find that troublesome. That that truth has to somehow be managed, within a dialogue. But on the other hand, there were some profound connections made. And it's, you know, I have read that Palestinians in the territories [of the West Bank and Gaza] only see Jews with guns, pushing them around, and Israelis only see Palestinians in suicidal bomb gear. So they don't know each other. They never see each other. So, I have mixed feelings about it, but it was an amazing experience.

A story from my field notes taken at a later Reconciliation Circle retreat helps to illustrate the complications of this kind of organized "relating." The event was the fourth annual retreat of this sort, hosted at a Jewish summer camp, but it was a much larger affair than it had been in years past, which presented some logistical problems for the organizers. With roughly 200 people in attendance, only a quarter were Arab or Arab American. The group was broken into groups of four for the first workshop of the day to allow each group member to speak uninterrupted for a minute about his or her feelings about each of a number of emotionally-and politically-loaded terms, including "right of return," "suicide bomber," and "Jerusalem," but many groups had no Arabs, mine included. Dora, a Canadian Jewish woman who was approximately 45 years old, and Orit, a 17-year-old Israeli woman, both expressed disappointment that our group had no Arabs. "I wanted to talk to some Arabs," Dora commented, "I wanted to hear their perspective." While Buber might see such claims as verging on $I$-it, objectifying experiences, the women's reactions were understandable. People invested a good deal of time and money, and traveled great distances, to come to this event, and they hoped to learn something new from it - to relate to Arabs. As it became clear to the organizers that some groups were without Arabs, the events were quickly reorganized. For the next session, our group was merged 
with a group that included Ali, a 30-ish Palestinian high school teacher from Jerusalem, and May, a Palestinian American woman who was about 45 years old whose father had helped organize the event. Ali started the discussion off, asking how our group's morning discussion had gone.

"It wasn't that interesting," said Dora, "We all pretty much agreed on things."

"Oh," challenged Ali, "so you all agreed that the Palestinian right of return would be a bad thing!"

"Well, I just don't know what would happen to us, to Israelis, to Jews," said Orit. "What would happen?"

"No one ever thought to ask what would happen to the Palestinians when the state of Israel was created on our land. Why should anybody ask what will happen to Israeli Jews now?"

"But it's my home," Orit replied. "Where would we go?"

"It was the Palestinians' home before. No one asked where we would go."11

The conversation continued in that vein with Ali at the center and members of the group taking turns asking him a question or presenting an alternative viewpoint, to which he would then respond. Facilitators circulated among the groups and would say things like, "Try not to talk about politics. Just focus on your feelings," as they walked by ours. At the time, I felt annoyed by the whole exercise. I was annoyed with Ali for assuming he knew what I thought, without giving me or anyone else a chance to actually speak his or her mind. I was annoyed that he had set the terms of the discussion. I was annoyed at the way he seemed to steamroll over a 17-year-old. As I reflected on the experience that afternoon, I thought about it another way: here was a Palestinian man visiting from West Jerusalem, coming to a Jewish camp, in the numerical minority, with Jewish prayers painted in brightly colored signs on the walls, in the United States, a major source of monetary and military support for the state of Israel. Everyone ostensibly came to work for peace, but what leads to peace? Talking about your feelings? Or asking questions about equality and what one sees as preventing it? Would it even be possible for him to talk about how he felt about the Palestinian right of return without talking about "politics"? Would such a discussion feel like anything more than "cheap, artificial, and mere words" (Emerson and Smith 2000, 58)?

Our discussion that afternoon felt like a failure, by the organizers' standards, because no one gave voice to any breakthroughs. No one embraced and said, "Now I know peace is possible." It felt pointless; it enacted Buber's description of debate with remarks "so pointed that they may strike home in 
the sharpest way, and moreover without the [people] that are spoken to being regarded in any way present as persons" $(1965,19)$. No one from our group was asked to speak at the concluding press conference. We were not a testament to the healing and transformative power of dialogue. Whenever I tried to find Ali later to see if he might sit down with me for an interview, he seemed to always miss my gaze and walk on. This is the paradox: as Habermas describes, formal world systems - politics - are entirely outside the lifeworld, although for Ali it might have been impossible to discuss his feelings without discussing the inescapable political realities into which he was born. Like Lisa, he might have found it more pressing to discuss actionable, concrete realities rather than the feelings of those who seemed to him to control his world with laws and military power. To open himself to dialogue in the way Buber describes could have been unthinkable in this context.

An anecdote from my previous fieldwork might help to shed light on Ali's situation. Because so many pro-gay members of religious communities come to their views through relating-to children, friends, siblings, and the likepro-gay movements often rely on the strategy of asking gay men or lesbians to speak informally to a group of interested members, a class, or a discussion group. But given that putative heterosexuals bear no stigma for their orientation and are often in the numerical majority that makes policy, such events can feel like an audition-either for oneself or on behalf of the entire stigmatized group-for full entry into the moral community, particularly if saying the wrong thing can affect the decisions of those with the authority to make policy. While this strategy may introduce the issues to people and inspire further thought and inquiry, I have neither seen nor heard of it changing many minds, particularly in cases where people are already firm in their convictions. Such forums seem more often to produce what Buber would call technical dialogues or monologues disguised as dialogue.

Midway through my research in United Methodist congregations, Jenny, a friend and key informant, invited me to join her at her parents' church where she had been invited to speak as a lesbian about what inclusion in the church meant to her. We had discussed my analysis that gay men and lesbians in my study were repeatedly cast as being pained and how "gay pain" became the reason for many members to welcome them into the church, and she was determined not to fall into that pattern; she was not in pain, and she believed there were compelling theological reasons for the church to welcome LGBT people. But the structure of the event itself caused a sort of pain, or at least a demonstration of pain. As the event began about twenty people sat in a circle and Jenny was introduced. She had prepared remarks around the theme that human beings cannot always know God's will, but that God can surprise people, calling us to do things that go against societal expectations. She began by reading scriptural stories of prophets and disciples being called to drop everything they knew in 
life and heed God's surprising call. But before she had completed her first sentence, she was in tears. She struggled to get her message out while crying, and soon several others, myself included, were crying as well and someone had to be dispatched to find a box of tissues. The very question at stake, the purpose for the gathering, was the question she had hoped to take as already answered: whether she had equal access to God's revelation, whether she was a full person in the eyes of God and the church, whether the stigma she bore resulted from social conventions or timeless truth. It is difficult for a community discussion of who belongs in the community-of who can speak for the community and who can only, at its discretion, speak to it-to produce conditions of full equality within that community since the question itself prefigures some members' exclusion.

In Udis-Kessler's (2008) research, inclusionists thought that if conservatives just "knew our people," they would change their minds; in the inclusionists' lifeworld, God makes some people gay, and same-sex love and intimacy teach people more about God's love. This knowledge comes from the relating that happens in the lifeworld, so their knowledge cannot be explained to their opponents in any satisfactorily objective-seeming terms. Those who believe homosexuality is sinful, on the other hand, see homosexuality and all it symbolizes to them (selfishness, carnality, politics, chaos, and the like; see Moon 2004) as firmly entrenched in the formal world-what evangelicals consider the fallen, human world. They cannot enter intersubjectivity with inclusionists because their prior understanding of homosexuality and what it symbolizes does not permit entrance into the realm of relating into their moral community. The symbolic violence LGBT people and their supporters experience in Udis-Kessler's study is the violence of being forcibly shut out of their lifeworld, their church, by those with the authority to do so-in terms of votes and tradition. In my own research $(2004,2005$ a), this pain became the admission price for the lifeworld to which they thought they had belonged all along: for gay and lesbian members to be seen as truly belonging in the church, they must perform pain; they cannot present themselves as whole persons simply seeking what any church member seeks in church. But to be forced to represent only one aspect of one's personhood-and a wounded aspect at that-is not relating; one's "whole self" is not quite welcome, but only the broken parts that fit within a particular, strategic narrative. That scenario becomes another of what Buber calls "faceless specters of dialogue" $(1965,20)$, in which one cannot relate or be related to because parts of oneself are silenced and one must take care to appear a certain way.

Returning to Ali at the retreat, to what extent does dialogue feel like "auditioning" for membership in the moral community of people who have a greater say than oneself over policies and the distribution of resources? As Diane asks, to what extent do some people's personal stories seem too "political" for 
dialogue, and what happens to dialogue when aspects of some personal stories are unspeakable? The goal of the weekend was to foster relating, and it succeeded in many cases. To relate to people previously outside one's lifeworld context involves some kind of feeling of sacrifice, for everyone involved. But to what extent might such an event feel to Palestinians the way it can feel for a gay person to be asked to speak to a group of people who may or may not believe that he or she is a living symbol of sin, fallenness, and carnality? To what extent might such a conversation feel like an audition to be recognized as fully human or a much-needed opportunity to convince those who might have more political leverage that there is something profoundly unfair happening that needs to be changed?

On a hike after the incident at the retreat, I spent some time getting to know a friendly man who was around 50 years old, a Jewish man named Saul. He expressed an interest in political discussions, so I asked him whether he thought there was anything odd about trying to talk about something like the Palestinian right of return without talking about politics. He gave it some thought and got back to me later, saying:

I was thinking about what you said and I had a conversation with a woman named Bobbie. She had a communication problem with a man that left her feeling misunderstood. They talked about it later and cleared it up. I think it's good that we leave politics aside and focus on just trying to understand each other. [Reconstructed in notes.]

He had a point, but after the event when I interviewed Jamil, a Palestinian involved in a Reconciliation Circle, he hesitated to answer many questions and repeatedly referred me instead to a local Palestinian advocacy group. I left our two-hour interview with the distinct impression that as a spokesperson for reconciliation, he did not feel he could say anything verging on the political.

\section{The Paradox of Dialogue}

As Buber argues about relating, Habermas argues that in communicative action, people are transformed. He writes:

Communicative action is not only a process of reaching understanding; in coming to an understanding about something in the world, actors are at the same time taking part in interactions through which they develop, confirm and renew their memberships in social groups and 
their own identities. Communicative actions are not only processes of interpretation in which cultural knowledge is "tested against the world"; they are at the same time processes of social integration and of socialization. $(1981,139)$

When a new grouping is formed, in the case of the Reconciliation Circle, or when the group's stated membership criteria are in flux, in the case of Protestant homosexuality debates, the collectivity and participants' personal self-concepts are redefined. But in cases like these that can be prefigured by tacit speech-rules about what can and cannot be said, particularly about power relations, these redefinitions are not complete, real though they may feel to those at the unacknowledged top of the hierarchy. These hierarchies, when unspoken, can be tacitly reproduced as well, particularly if there are double standards about who can tell his or her own story in his or her own way, whose story is legitimate, and what kinds of personal truths are too "political" to be uttered. In those cases, stigmatization is reproduced, even as those closer to the top of the hierarchy genuinely feel that they have transformed, given of themselves, or made themselves vulnerable in the name of reconciliation. The gag rule impedes those at the bottom from being fully expressive, from feeling understood, and perhaps from being transformed in the process. As Buber (1988 [1965]) posits, genuine dialogue is free from needing to appear a certain way to another. However, if people are allowed to "discuss politics," then the whole concept of dialogue could easily revert to the polarized conflict dialoguers commit to sacrificing and transcending. This is the paradox.

There are solutions to this paradox. One is to avoid dialogue altogether, ridiculing it as naively idealistic or banal or seeking to discredit its participants as traitors. On the other hand, some maintain that politics and relationship come together; they commit to solidarity and can hear political critiques of their own power and privilege without feeling personally attacked. Politicization can light a path forward. When genuine dialogue occurs, people feel transformed, spoken to, understood. But the line between genuine dialogue and the imitations Buber discusses is not always clear. When genuine dialogue happens, social hierarchies that were previously naturalized can come to seem profoundly arbitrary and unfair. But since dialogue cannot be objectively assessed, a semblance of it can renaturalize the hierarchies it fails to demystify. Still, dialogue and the relating that takes place in it are real phenomena that we need to consider when we think about hierarchies in communities and when we think about the relationship between social power and the self. Indeed, when we ignore it, we cannot understand the social change that happens, and does not happen, in communities bound by relationship. 
Taking reconciliation/dialogue seriously calls us to consider the boundaries people draw between social convention and timeless truth, lines straddled by both institutional knowledge (religious and otherwise) and extra-institutional forms of knowledge (religious and otherwise). If sociologists consider only institutional religion in our studies of how people make their lives meaningful, we close our eyes to the fact that to be defined as "truth" one must define it-whatever one believes it to be-as transcendent. In that sense, religious and nonreligious contexts overlap considerably (and where a person feels at home depends on where one has found truth). Acknowledging that considerable overlap, we can see more clearly the profound ways in which those with more privilege to define the terms of dialogue can-as they try sincerely to express what feels deeply true to them-delegitimize others' truths, and silence the very people with whom they wish to reconcile.

\section{Acknowledgment}

I wish to thank Jonathan VanAntwerpen, Steve Warner, and the editors of this volume for helpful comments and feedback, and the respondents who gave me the gifts of patience and insight as they made this project possible.

\section{Notes}

1. As Gamson (1992) discusses, the naming of this conflict is itself highly controversial. Given that many of the Arabs most directly implicated in this struggle identify as Palestinian and are identified by other respondents as such, I use this term. I thus refer to the conflict as the Israeli-Palestinian conflict.

2. In addition, I conducted two focus groups involving another twenty-seven respondents.

3. To protect confidentiality, names and some identifying details of people and organizations have been changed.

4. Helpful summaries of the ideological and political tensions appear in Lerner (2003) and Ruether and Ruether (2002).

5. For a more representative study of American Jewish attitudes, see Cohen and Eisen (2000).

6. British legal scholar Anthony Julius has argued that the state of Israel's founding father Theodor Herzl envisioned that with their own state, Jews would have "ordinary enemies," fighting over ordinary things like borders and resources (Julius 2007; see Herzl 1988 [1896], chapter IV).

7. Habermas (1981) makes a similar argument but does not discuss Buber.

8. While $I c h-D u$ is conventionally translated as I-thou, Kaufmann argues that this translation, with the archaic quality of "thou," fails to capture the familiarity of $D u$, the intimate you that a child would use with his or her parents or that intimate friends use, which is what Kaufmann argues that Buber intends.

9. Printed in Buber (1965).

10. Respondent quotations are from recorded interviews unless otherwise noted and have been edited for readability (for instance, by removing extraneous ut terances such as "um" and "like").

11. These discussions were reconstructed in field notes. 


\section{References}

Baumann, Zygmunt. 1989. Modernity and the Holocaust. Ithaca, NY: Comell University Press.

Benvenisti, Meron. 2002. Sacred Landscape: The Buried History of the Holy Land Since 1948. Berkeley: University of California Press.

Buber, Martin. 1965. Between Man and Man. New York: Macmillan Publishing Co.

- 1970 [1923]. I and Thou, translated by Walter Kaufmann. New York: Simon and Schuster.

1988 [1965]. Knowledge of Man. New York: Harper and Row.

Chesler, Phyllis. 2003. The New Anti-Semitism: The Current Crisis and What We Must Do About It. San Francisco: Jossey-Bass.

Cohen, Steven M., and Arnold M. Eisen. 2000. The Jew Within: Self, Family and Community in America. Bloomington: Indiana University Press.

Dershowitz, Alan. 2003. The Case for Israel. Hoboken, NJ: John Wiley and Sons.

Durkheim, Emile. 1995 [1912]. Elementary Forms of the Religious Life. New York: Free Press.

Emerson, Michael O., and Christian Smith. 2000. Divided by Faith: Evangelical Religion and the Problem of Race in America. New York: Oxford University Press.

Fein, Helen. 1979. Accounting for Genocide. New York: Free Press.

Foxman, Abraham H. 2003. Never Again? The Threat of the New Anti-Semitism. San Francisco: Harper.

Gamson, William A. 1992. Talking Politics. New York: Cambridge University Press.

Habermas, Jürgen. 1981. The Theory of Communicative Action, Vol. 2: Lifeworld and System: A Critique of Functionalist Reason. Boston: Beacon Press.

Herzl, Theodor. 1988 [1896]. The Jewish State. New York: Scopus.

Hunter, James Davison. 1992. Culture Wars: The Struggle to Define America. Basic Books.

Julius, Anthony. 2007. "When Legitimate Dissent Crosses the Line." Keynote address given at Finding Our Voice: The Conference for Progressives Constructively Addressing Anti-Semitism, San Francisco, January 28.

Lerner, Michael. 2003. Healing Israel/Palestine: A Path to Peace and Reconciliation. Berkeley, CA: Tikkun Books.

Mead, George Herbert. 1967 [1934]. Mind, Self, and Society from the Standpoint of a Social Behaviorist. Chicago: University of Chicago Press.

Moon, Dawne. 2004. God, Sex, and Politics: Homosexuality and Everyday Theologies. Chicago: University of Chicago Press.

2005a. "Emotion Language and Social Power: Homosexuality and Narratives of Pain in Church." Qualitative Sociology 28(4): 325-347.

2005b. "Discourse, Interaction, and the Making of Selves in the US Protestant Dispute over Homosexuality." Theory and Society 34: 551-577.

Ruether, Rosemary Radford, and Herman J. Ruether. 2002. The Wrath of Jonah: The Crisis of Religious Nationalism in the Israeli-Palestinian Conflict. 2nd ed. Minneapolis, MN: Fortress Press.

Smith, David Norman. 1996. "The Social Construction of Enemies: Jews and the Representation of Evil." Sociological Theory 14(3): 203-240.

Tavuchis, Nicholas. 1991. Mea Culpa: A Sociology of Apology and Reconciliation. Stanford, CA: Stanford University Press.

Todd, Jennifer, 2005. "Social Transformation, Collective Categories, and Identity Change." Theory and Society 34: 429-463.

Udis-Kessler, Amanda. 2008. Queer Inclusion in the United Methodist Church. New York: Routledge.

Yancey, George. 1998. "Reconciliation Theology: Results of a Multiracial Evangelical Community." Paper presented at the Color Lines of the Twenty-First Century Conference, Chicago; cited in Emerson, Michael O., and Christian Smith. 2000. Divided by Faith: Evangelical Religion and the Problem of Race in America. New York: Oxford University Press, $54-55$. 